\title{
The mode and method research of Chinese traditional culture integrated into the College students' ideological and political education
}

\author{
Xiaolin Tian ${ }^{1}$, Xiaofei Wang ${ }^{2, *}$ \\ ${ }^{1}$ Hainan College of Economics and Business, China \\ ${ }^{2}$ Hainan Medical University, China \\ *Corresponding author
}

Keywords: Chinese traditional culture, college students, ideological and political education mode, and education method.

\begin{abstract}
Long and splendid Chinese traditional culture, its implication of the profound philosophy and advanced thought is a valuable ideological and political education resource. As an ideological and political education worker, we should derive the essence of traditional culture, to strengthen the values education of young students and realize the development and innovation of contemporary ideological and political education, continuously in practice to carry forward Chinese traditional culture.
\end{abstract}

\section{Introduction}

College students is the main bearing on the development of the society, the ideological and political education of college students and ethical diathesis of the development of economic construction of our country is very big, the influence of the traditional cultural spirit and college students' ideological education, the author used Marxist education philosophy way of thinking, combined with traditional Chinese Confucianism thought, contact at present in today's China's actual conditions, the Chinese long traditional culture into the current ideological and political education in colleges and universities, to solve the problem of the guide the ideological and political education [1].

Extensive and profound Chinese culture has a long history. During thousands of year's culture heritage, culture infiltration in the political, economic, etc., to form the national culture with distinctive characteristics. Impetus to the development of the national cultural development, cultural motivation enhances the cohesion of the country.

In today's society is a social, economic, political and cultural globalization diversification with the development of the economy since the reform and opening up, the impact of the Internet leads some of the ideas constantly the social ideological trend. Western culture shock on the campus of the University of China, influence the concept of college students [1]. These western ideas can lead to some students' outlook on life and values distorted; it will also affect college students' life value orientation. College students are the main power in the future construction and development. For the outstanding culture should gradually into the ideological and political education of college students, to improve college students' knowledge structure, cultivate and carry forward the national spirit of college students.

\section{The reasons excellent traditional culture education in college students' ideological loss}

Since reform and opening up, in different parts of the mind constantly in-depth, as under the wave of western thought, culture, diversity of values have flooded Chinese society. For people's ideological concept formed the powerful impact of college students as an emerging group, their thought is active, curious, easily attracted by new things [2]. For a long time, various universities did not attach enough 
importance to the education of traditional culture, groups of college students is the lack of traditional cultural spirit, for lack of interest in traditional culture, some students even think that traditional culture is outdated.

Most of the students think, of the Chinese nation outstanding traditional culture is the core of the Confucian classics; always show the national wisdom and traditional virtue. Now with the transformation of social economic development and the negative impact of pluralistic society, most of the students for traditional virtue concept consciousness are relatively weak. At the same time, they too materialistic value orientation, to their own traditional culture value [2]. A lot of colleges and universities often embark from the social demand, the demand of these ideas is in order to improve the grades, cultivate professional talents, and neglect humanities education. The lack of education mode is the lack of culture.

The country's development cannot leave the development of culture. The Chinese nation in the long-term historical development process have some cultural concept affects people's thoughts, also affects the development of the society [1]. China's traditional culture is by passed down from generation to generation, the connotation of culture has penetrated into the political, social and ecological aspects, economic field, in particular, has been formed with their good values and our way of thinking.

In recent years, the academic circles in China more and more excellent cultural works, a lot of people also become more widely to the understanding of traditional culture. Chinese excellent traditional culture in the long historical is development of the Chinese people for thousands of years, with an unyielding enterprising spirit, the national spirit of patriotism, of the unity of nature and the humanities spirit.

\section{The outstanding traditional culture spirit of education}

Culture as the national soft power, for the construction of college students' ideological and moral education, must pay attention to the excellent traditional culture of learning. In colleges and universities ideological and political education, cultivate good students set up their correct outlook on life, values, and inspire their collectivism and patriotism, enhance national cohesion and centripetal force, the development of socialist culture at the same time, the construction of spiritual civilization [2].

To college students to establish a good sense of mission and social responsibility, the patriotism emotion always translated into action. Let the combination of traditional culture and modern science and technology, to attract college students to participate in the study of traditional culture. Carry forward and cultivate the patriotism as the core of the great national spirit, stimulate students' patriotism and collectivism.

The Chinese excellent traditional culture into the necessity of the ideological and political education. The Chinese excellent traditional culture into the ideological and political education is to promote college students' ideological and political education work important requirement. Chinese excellent traditional culture is an important cultural treasures, is the crystallization of the wisdom of Chinese children, precipitation is thousands of years of Chinese civilization in the history of the nutrient. Chinese excellent traditional culture of the generation, accumulation effectively regulates the human beings, between human and nature, man and society, the relationship between the leads people to set up the correct values, outlook on life and world view [3]. Chinese excellent traditional culture is coordinate the relationship between heavens, earth, between a pair of good agent. In Confucianism, for example, Confucianism is the typical representative of the Chinese traditional culture, Confucian essence thought contains a lot of excellent traditional culture, it is the holy king, benevolence, for internal requirement, for external specification with courtesy thought system. Although the dross and the essence of Confucianism set, but Confucius Confucianism emphasizes inner moral self constraint, emphasizes the social implementation pattern by his talent.

Chinese excellent traditional culture into the ideological and political education is the realistic requirement of ideological and political education present situation. Along with the rapid development of globalization, the deepening of the market economy transition and social 
structure change sharply and the profound adjustment of the interest distribution pattern, some college students under the influence of other values in different degrees, in the sense of responsibility is not strong, weak ego consciousness, self-discipline ability, weak will quality and psychological quality, etc [3]. Vigorously strengthen ideological and political education work, guides the student to set up the correct outlook on life, values and world view, is particularly important.

\section{Excellent traditional culture of the value of college students' ideological and political education}

Help to improve college students' ideological and moral realm. Mencius on the doctrine of standards, "move no money and rank can confuse, no poverty," fears, shine with the brilliance of the thought and personality power, encourage people to justice, intrepidity, living out our character. Lin zebu's "empty sea, tolerance is a great" said to be a person to have broad like the sea mind to all-encompassing. "Harmony without uniformity, seeking common ground while putting aside differences" reflects is the tolerance of the spirit of esteeming harmony [3]. These good moral principles and traditional will improve the level of college students' ideological and moral, forming perfect personality and subtly influence to their personal principles and way, and encouraging them to create a good, harmonious, mutual relationships, to enhance their social adaptation ability and cultivate their teamwork spirit also has extraordinary significance.

Help students establish positive attitude towards life. Mencius' prosperity, die "point of view, and inspired countless lofty ideals strive in adversity, verifying the" s) in the practice, "this simple truth. When aim high" motivate young people should be ambitious. At present, plaything weary in well doing, some students' waste studies, this is a manifestation of the lack of social responsibility; Part of college students pay attention to wear and flaunt wealth than rich, objective conditions has been slightly $\mathrm{f}$ to complain, this is the performance of the arduous struggle spirit down [4]. According to these symptoms, strengthen the excellent traditional culture of learning and understanding is the best medicine.

Help to cultivate students' patriotic feelings. Excellent traditional culture is lighted up with flashes bright patriotism, such as Lao zi proposed "to their DE is abundant, the trim is to the world its DE is general" thought;"Rites" as described in "the world" "Datong world" has been yearning for posterity; X.Zh. Xu, although nine dead it especially no regrets" will be his love to the people and the country's faithful feelings expressed incisively and vividly. Zh.Y. Fan mentioned the world of joy but joy still thinking often admired by later generations. Therefore, adhere to the excellent traditional culture can be incorporated into the ideological and political education can help cultivate their patriotic feelings.

To promote college students to make contribution to the national modernization construction. For a country, the modernization is rich nourishing of grounding for the nation, such as rapid economic development, like the United States, Britain culture is relatively more developed countries. It is traditional culture and relies on the development of the national economy fusion. With the influence of economic globalization, increasing scientific and technological level, the development of market economy and the comprehensive national strength has been enhanced. Students as an important talent reserves in the construction of modernization, in the process of the development of the national modernization, the student is the main driving force and the undertaker [4]. There is a widespread, the current college students' traditional culture the scarce knowledge study, think that the traditional cultures have been out of date, for the understanding of the traditional virtue of the concept is relatively weak, and the value of traditional culture to seriously enough. For them, it is very urgent to the education of traditional culture is, college students in the process of promoting and developing Chinese excellent traditional culture, help to make a significant contribution to the national economy. 


\section{Excellent traditional culture into the effective way of college students' ideological and political education}

In campus culture construction as the carrier, completes the propaganda work of excellent traditional culture. The cultivation of the campus culture to people can play "the wind into night moistens everything silently". Hardware, can through the school radio station, TV station, publicity column, sketch, calligraphy inscriptions on campus, building decoration and other forms of propaganda and the excellent traditional culture, the traditional culture of create a good atmosphere. As a result, the students "eyes ears dyed speech \&drama, not learn to". Campus culture festival, the theme in software, activities, theme class meeting, club activities as the carrier, actively carry out the popularization of traditional culture, such as speech contest, debate, knowledge contests, culture salon, lectures, etc; it is to make full use of new media in promoting the unique role of excellent traditional culture [5]. The current network has made college students' way of life and its access to knowledge, profound changes have taken place in colleges and universities should adapt to the trend of The Times, completes the excellent traditional culture into the work, such as building contains the excellent traditional culture of the campus culture APP client, etc. Only in this way, can improve the effectiveness of the ideological and political education of college students' work and targeted.

Reform the education content, teaching mode innovation. At present, the higher education of Chinese traditional culture into the program phenomenon is also one of the few, education contents of the reform in colleges and universities. Traditional culture is the soul of the Chinese nation, has deep into every Chinese people's blood, as college students, and should shoulder the important task of studying and inheriting the excellent traditional culture [5]. In the future, the country should attach importance to the traditional culture in the form of a required course into the plans for students, makes the fine traditional culture teaching materials, so that traditional culture will be Chinese, thought morals tutelage and legal foundation and the university and other political course form resultant force, effective connection, in order to improve the students' cultural quality and moral level, help them form the correct values and outlook on life.

The teaching way has two kinds of transmission theory and practice. In the traditional culture of classroom teaching, must renew the idea, to avoid a single infusion and preach, attaches great importance to the role of multimedia in the teaching, pay attention to exert students' enthusiasm and initiative, to carry out various forms, vivid and closely integrated with social hot issues T.Sh. Tan, heuristic learning [6]; The role of practical education in traditional culture learning, actively guide college students out of school, carry out social practice and voluntary service, study Tours and other activities, so that the students really in practice to comprehend the true meaning of excellent traditional culture and charm.

To strengthen the construction of teachers, talented person basis. Excellent traditional culture into the key of the college students' ideological and political education lies in the construction of teachers' team. Because the teacher is the project main body implementation, and shoulders on the responsibility education and training of the students are at the same time. "Learn W.Sh. Gao, so the teacher must pay attention to personal moral cultivation, mannerisms, especially must pay attention to improve their in the traditional culture knowledge reserves and knowledge level; Must be good at using traditional culture to analyze the social hot issues, is good at with cultural visual analysis to solve practical problems faced by students [6]. Only in this way, the ideological and political education work to be more persuasive. In addition, colleges and universities should pay much attention to teachers engaged in the work of ideological and political education on the traditional culture of training and education, as the excellent traditional culture into the college students' ideological and political education the system project lay a solid talent base.

Chinese traditional culture is the Chinese nations in the long historical development process of gradually formed and in turn affect the society as a whole, have relatively stable common spirit, psychological state, thinking mode and value orientation, etc. Its content is extensive and profound, has its important influence in Asia and the world. Contemporary college students' ideological and political education should be rooted in the national soil, fully absorbing the traditional nutrient, inheritance develop the excellent culture of the Chinese nation, full to the value of traditional culture 
connotation [6]. But for a long period of time, the Chinese traditional culture has been left out of ideological and political education. On the basis of a comprehensive understanding to strengthen the education of Chinese traditional culture, is the enormity of the task facing the ideological and political education workers.

\section{Summary}

Chinese traditional culture rich and colorful, all-encompassing, throughout the history of the growth of the Chinese nation, guided China experienced a brilliant once again. We should take its essence and discard its dross, on the basis of a comprehensive understanding to strengthen the education of Chinese traditional culture, the traditional Chinese culture and the ideological and political education of college students, for our country's socialist modernization construction to provide the inexhaustible power. Correctly handle the relationship between traditional culture and modernization, the Ming contend with traditional culture concept, the value orientation of young people, to strengthen the youth generation to achieve socialist modernization sense of responsibility and historic sense of mission, to modernize the traditional culture and promote each other, a breakthrough in traditional culture in the era of ideological and political education, is the enormity of the task facing the ideological and political education workers. As colleges and universities ideological and political education workers, a long way to go, not a little slack.

\section{References}

[1] L. Y. Cui, The China traditional culture and contemporary college students' ideological and political education, Beijing: Beijing normal university, 2015, vol. 1, pp. 23-26.

[2] X. H. Zhang, Stone bin the China traditional culture and the innovation of ideological and political education, 2011, vol. 6, pp. 54-57.

[3] Zh. J. Liu, Chinese traditional culture in the role of ideological and political education, 2013, vol. 4, pp. 33-37.

[4] L. M. Yan, Education to the role of traditional culture in ideological and political education, Journal of Shaanxi normal university: philosophy and social science edition, 2007, vol. 3, pp. 32-35.

[5] J. B. Zhu, Theory of Chinese traditional culture in the role of ideological and political education, A new perspective, 2005, vol. 2, pp. 15-19.

[6] Y. H. Zhang, Introduction to Chinese traditional culture, Hangzhou: Zhejiang University press, 2005, vol. 3, pp. 31-35. 